Original articles

J. Perinat. Med.

5 (1977) 76

\section{Role of assays of total estriol in amniotic fluid for the diagnosis of fetal hypotrophy}

\author{
G. Bacigalupo, J. W. Dudenhausen, E. Saling
}

Unit of Perinatal Medicine - The Free University of Berlin

Department of Obstetrics, Berlin-Neukölln

\section{Introduction}

In hypotrophic fetuses and newborn infants perinatal morbidity and mortality are much increased compared to those in eutrophic infants $[11,13]$. In severe cases, brain development in the small-for-date babies may be impaired $[4,5,14$, 22, 23].

Detection of these high-risk infants and assessment of their well-being prior to birth are of considerable interest to the obstetrician since he may hereby obtain useful indications for therapy.

The diagnosis of fetal hypotrophy is now generally made by ultrasonic measurement of fetal size and hormone assays. In this connection, estriol is one of the compounds in amniotic fluid which has attracted attention. Estriol, which is synthesized in very large amounts during late pregnancy, is almost entirely a product of the feto-placental unit [3]. Since amniotic fluid is free of direct maternal influences, it is conceivable that its estriol concentrations will reflect current fetal and placental function and fetal development.

The major objective of this study has been to examine estriol concentrations in amniotic fluid in eutrophic and hypotrophic infants and then to clarify whether and to what extent estriol assays in the liquor may contribute to the antenatal identification of intrauterine hypotrophy.

\section{Patients, materials and methods}

In 108 pregnancies (gestational weeks 31 to 41 ) 127 samples of amniotic fluid were assayed for their concentration of total estriol. Antepartally the samples were obtained by transabdominal amniocenteses, indicated for various clinical reasons; subpartally amniotic fluid was withdrawn following transcervical puncture of the amniotic cavity. Among the pregnancies examined there were 74 pregnancies with eutrophic infants (Group A) and 34 with hypotrophic infants (Group B). The infants were classified in one of the two groups by gestational age and birthweight [12]. Gestational age was determined by means of menstrual history, the first maternal perception of fetal movements and the degree of maturity immediately after delivery, the estimation of which was made according to the clinical criteria proposed by FARR and Petrussa $[6,17]$. For the assessment of the birthweights of the neonates at a particular gestational age the birthweight curves according to NICKL were employed [16]; they describe the relative frequency of neonatal birthweights by week ofgestation for the present German population. Hypotrophic neonates were defined as infants whose birthweights lay below the $3 \mathrm{rd}$ percentile according to NiCKL.

Total estriol in amniotic fluid was assayed by a chemical method for highly specific estriol determination [1]. The special features of the assay are as follows:

a) clear-cut TLC-separation of estriol from the rest of the phenolic fraction of the sample,

b) characterization of the sample estriol spots by comparison of position with reference estriol spots run in parallel, 
c) direct quantification of estriol spots by reflectance spectrophotometry on the chromatogram,

d) computer-assisted evaluation of the recorded reflectance values applying the KUBELKAMUNK equation.

The high specificity of the estriol assay used results from the direct measurement within the chromatographically pure estriol spot. In a range from 40 to $400 \mathrm{ng}$ estriol per spot, the precision of the method was \pm 4 per cent. The recovery rate of known amounts of estriol added to sample material prior to assay varied from 70 to 80 per cent. With amounts of $40 \mathrm{ng}$ estriol per spot, the lower limit of sensitivity for reliable reflectance measurements was reached. For total estriol assays by means of the above-cited method, amniotic fluid samples of 5 to $10 \mathrm{ml}$ were used. Until processing, the samples were stored at $-20^{\circ} \mathrm{C}$.

\section{Results and comments}

A survey of the clinical data concerning the groups examined is given in Tabs. I and II. The mean weight of the hypotrophic neonates was $758 \mathrm{~g}$

Tab. I. Clinical data on the groups investigated.

\begin{tabular}{|l|c|l|}
\hline & $\begin{array}{l}\text { Eutrophic } \\
\text { neonates }\end{array}$ & $\begin{array}{l}\text { Hypotrophic } \\
\text { neonates }\end{array}$ \\
\hline Mean body weight $(\mathrm{g})$ & 3149 & 2391 \\
\hline Mean placental weight $(\mathrm{g})$ & 566 & 428 \\
\hline Saling score (points, $\bar{x})$ & 9.8 & 8.5 \\
\hline Vaginal delivery & $85 \%$ & $71 \%$ \\
\hline Sectio caesarea & $15 \%$ & $29 \%$ \\
\hline $\begin{array}{l}\text { Total number of infants } \\
\text { examined }\end{array}$ & $74(=100 \%)$ & $34(=100 \%)$ \\
\hline
\end{tabular}

Tab. II. Disturbances immediately post partum in the neonates examined. - Depression $\leqslant 6$ points of the score according to SALING [18]. Respiratory acidosis $=\mathrm{pH}$ act. $\leqslant 7.19$ and $\mathrm{CO}_{2}$ overload in arterial cord blood. Metabolic acidosis $=\mathrm{pH}$ qu $40 \leqslant 7.19$ in arterial cord blood.

\begin{tabular}{|l|l|l|}
\hline & $\begin{array}{l}\text { Eutrophic } \\
\text { neonates }\end{array}$ & $\begin{array}{l}\text { Hypotrophic } \\
\text { neonates }\end{array}$ \\
\hline $\begin{array}{l}\text { Depression of the neonate } \\
\text { immediately post partum }\end{array}$ & $3=5.4 \%$ & $11=32.4 \%$ \\
\hline $\begin{array}{l}\text { Respiratory acidosis } \\
\text { immediately post partum }\end{array}$ & $6=8.1 \%$ & $6=17.7 \%$ \\
\hline $\begin{array}{l}\text { Metabolic acidosis } \\
\text { immediately post partum }\end{array}$ & $3=4.0 \%$ & $4=11.8 \%$ \\
\hline $\begin{array}{l}\text { Total number of infants } \\
\text { examined }\end{array}$ & $74=100 \%$ & $34=100 \%$ \\
\hline
\end{tabular}

lower than that of the eutrophic neonates, whereas the mean placental weight in the hypotrophic group was by $138 \mathrm{~g}$ lower than that in the eutrophic group. The clinical status of the hypotrophic infants immediately post partum, as judged by our modified score [18], was diminished in comparison to that of the eutrophics; in addition, the hypotrophic neonates had more frequently been developing acidoses. One of the 74 eutrophic infants died within 24 hours after delivery (1.4 per cent), on the contrary, 3 of 34 hypotrophic infants perished during the perinatal period ( 8.8 per cent).

The analysis of the maternal, pregnancy-associated disturbances and diseases is rather interesting. The complication rate in the mothers of the eutrophic neonates was 5.4 per cent ( 2 cases of gestational diabetes mellitus, 1 case of abortus imminens, mens IV, 1 case of active toxoplasmosis; $n=74$ ). In contrast, the complication rate in the mothers of the hypotrophic infants amounted to 55.9 per cent, i.e. approximately tentimes the former complication rate (14 cases of toxemia, 4 cases of gestational diabetes mellitus, 1 case of abortus imminens, mens III, 1 case of vitium cordis; $n=34$ ).

Figs. 1 and 2 show the distribution of the concentrations of total estriol by age of gestation in the two groups examined. With advancing gestational age a conspicuous rise of total estriol concentrations in amniotic fluid is to be encountered. At gestation weeks 37 to 41, at "term", the mean total estriol values are more than twice as high as those in the four gestational weeks before (Tab. III). This pattern is valid for the pregnancies with eutrophic infants as well as for those with hypotrophic progeny.

In general the total estriol concentrations in amniotic fluid in pregnancies with hypotrophic infants lie much lower than those in pregnancies with eutrophic infants. The differences are statistically significant $\left(P<0.001, \chi^{2}=28.55\right.$ and 22.33 respectively, 1 degree of freedom). The mean values of total estriol in amniotic fluid in the hypotrophic group amount to only 42 and 43 per cent of those in the eutrophic.

There is an overlapping in the estriol ranges of both groups. This implies that a normal total estriol concentration measured in amniotic fluid does not necessarily exclude fetal hypotrophy. 




Fig. 1. Distribution of total estriol concentrations in amniotic fluid, related to gestational age: Pregnancies with eutrophic infants. Squares = antepartal values; dots = subpartal values.

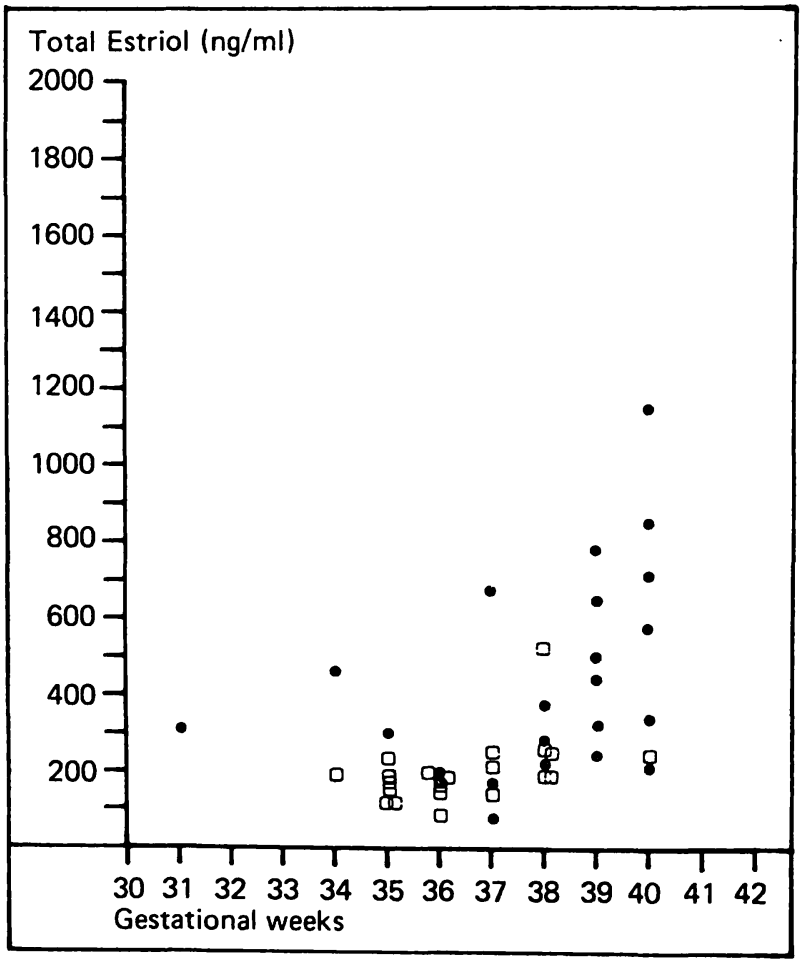

Fig. 2. Distribution of total estriol concentrations in amniotic fluid, related to gestational age: Pregnancies with hypotrophic infants. Squares = antepartal values; dots $=$ subpartal values.
Nevertheless, some clinically remarkable features of the present data material must be emphasized. At gestational weeks 33 to' 36 only one out of 29 estriol values in the eutrophic group lies below the level of $200 \mathrm{ng}$ per milliliter, at weeks 37 to 41 three out of 48 estriol values lie below the level of $400 \mathrm{ng}$ per milliliter of amniotic fluid. On the other hand, at gestational weeks 33 to 36 not a single one out of 16 estriol values in the hypotrophic group exceeds the level of $500 \mathrm{ng}$ per milliliter, at weeks 37 to 41 one out of 26 values in the same group lies above the threshold of $1000 \mathrm{ng}$ per milliliter of amniotic fluid.

The mean total estriol values in amniotic fluid obtained from term babies at the day of delivery (Tab. IV) are slightly greater than the corresponding values in Tab. III which represent estriol values obtained antepartally and subpartally. These findings support the view that, near term, total estriol concentrations continue to rise up to the day of delivery, as they also do in normal pregnancies and in pregnancies with hypotrophic infants.

Comparison of the mean birthweights in the eutrophic and hypotrophic group and comparison of the mean total estriol concentrations in amniotic fluid in both groups show noteworthy results. While the mean birthweight in the hypotrophic term neonates amounts to 73 per cent of that in the eutrophic term neonates, the mean estriol concentration in the hypotrophic group amounts to only 47 per cent of the corresponding value in the eutrophic group. In other words, compared to the eutrophic babies, the growth deficit in the hypotrophic babies ( 27 per cent) is much smaller than their estriol deficit (53 per cent) in amniotic fluid. This finding supports our assumption that estriol assays in amniotic fluid are an useful tool in diagnosing intrauterine hypotrophy.

\section{Discussion}

Determinations of estriol in maternal urine and plasma are generally accepted by obstetricians as being useful ways of following the condition of the fetus. Examination of amniotic fluid is the closest diagnostic approach which can be made to the fetus in situ. As is known, the steroid hormone patterns in the fetus and in amniotic fluid are very 


\begin{tabular}{|l|r|l|l|l|l|l|}
\hline & \multicolumn{3}{|l|}{$\begin{array}{l}\text { Eutrophic } \\
\text { infants (A) }\end{array}$} & \multicolumn{2}{l|}{$\begin{array}{l}\text { Hypotrophic } \\
\text { infants (B) }\end{array}$} & \\
\hline Gest. weeks & $n$ & $\begin{array}{l}\text { Total estriol } \\
\text { (ng/ml) } \bar{x} \pm \mathrm{s}\end{array}$ & $n$ & $\begin{array}{l}\text { Total estriol } \\
\text { (ng/ml) } \bar{x} \pm s\end{array}$ & $\begin{array}{l}\text { Statistical } \\
\text { significance }\end{array}$ & $\frac{E}{E} \bar{x}(B)$ \\
\hline $37-41$ & 48 & $943.8 \pm 464.8$ & 27 & $392.2 \pm 258.9$ & $p<0.001$ & 0.42 \\
\hline $33-36$ & 29 & $430.0 \pm 191.7$ & 16 & $185.7 \pm 86.2$ & $p<0.001$ & 0.43 \\
\hline $30-32$ & 6 & $176.7 \pm 78.2$ & 1 & ") & -- & - \\
\hline
\end{tabular}

Tab. III. Comparison of total estriol concentrations in amniotic fluid in pregnancies with eutrophic and hypotrophic infants. Calculations of statistical significance of the estriol differences by means of $X^{2}$-test; $n=$ number of amniotic fluid samples assayed. x) 1 value only (see Fig. 2).

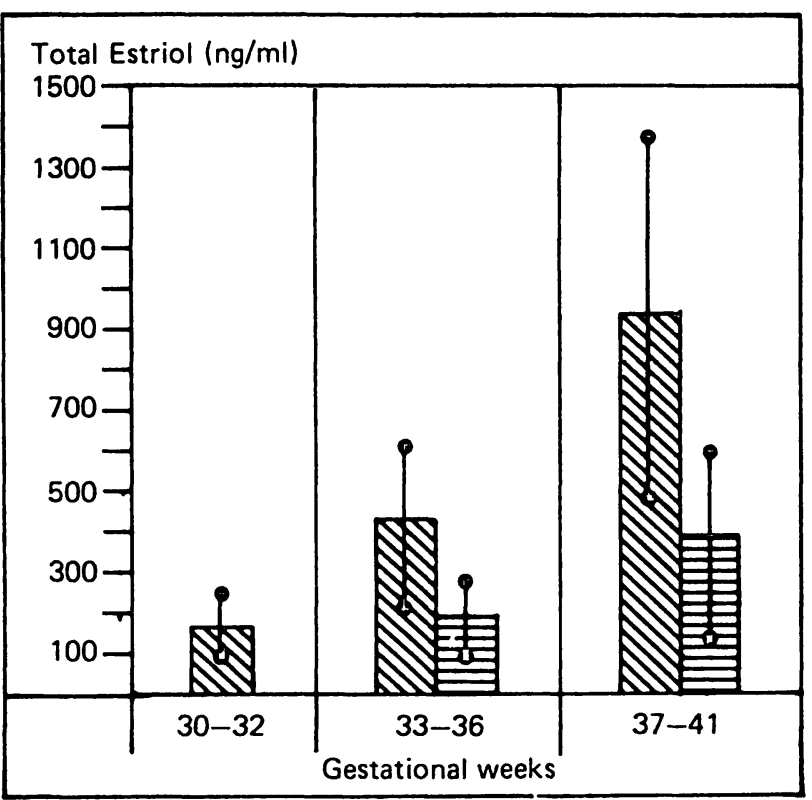

Fig. 3. Concentrations of total estriol in amniotic fluid; arithmetical means and standard deviations.

Values in eutrophic infants = diagonally hatched columns; values in hypotrophic infants = transversely hatched columns.

similar to each other. The steroids present in amniotic fluid chiefly originate from the excretions of the fetus - mainly from its micturition - and there exists a dynamic equilibrium between amniotic fluid and maternal circulation $[2,19,20]$. Thus, it may be suggested that estriol concentrations in amniotic fluid reflect the current fetal and placental function to a certain degree. There are also good reasons for supposing that maternal influences such as her metabolism and excretory functions, intake by the mother of fluids, alcohol, nicotine, drugs etc. produce more attenuated effects upon the estriol conditions in the fetoplacental unit than upon those in maternal plasma and urine.
The total estriol concentrations in the amniotic fluid which we measured in eutrophic infants are in agreement with representative estriol data from other authors $[7,9,19]$.

In both groups investigated the rise in the estriol concentrationsis persistentup to the day of delivery. The scatters of the estriol values are large. According to the result of this investigation it is beyond question that as a rule hypotrophic infants have significantly lowerestriol concentrations in amniotic fluid than eutrophic infants at the same gestational age.

Considerable diagnostic uncertainities result from the fact that there is a gond deal of overlap between the estriol concentrations in amniotic fluid of eutrophic and those of hypotrophic infants. Indeed, in cases showing low-normal estriol values in amniotic fluid one cannot safely distinguish by the estriol values alone whether the appropriate fetus is eutrophic or not. In such a situation a diagnostic assessment of the estriol data can be tried by combining them with other chemical and clinical findings in the pregnancy under examination. For the correct assessment of the estriol values it is important that the antenatal calculation of gestational age is accurate.

As already mentioned, definite marginal estriol values are of great diagnostic value. At gestational weeks 33 to 36 and 37 to 41 total estriol concentrations in amniotic fluid below the level of $200 \mathrm{ng}$ per $\mathrm{ml}$ and below the level of $400 \mathrm{ng}$ per $\mathrm{ml}$ respectively are indicative of fetal hypotrophy. In the contrary, total estriol concentrations above $500 \mathrm{ng}$ per $\mathrm{ml}$ and $1000 \mathrm{ng}$ per $\mathrm{ml}$ at weeks 33 to 36 and weeks 37 to 41 respectively are generally not consistent with fetal growth retardation (see Tab. IV). 


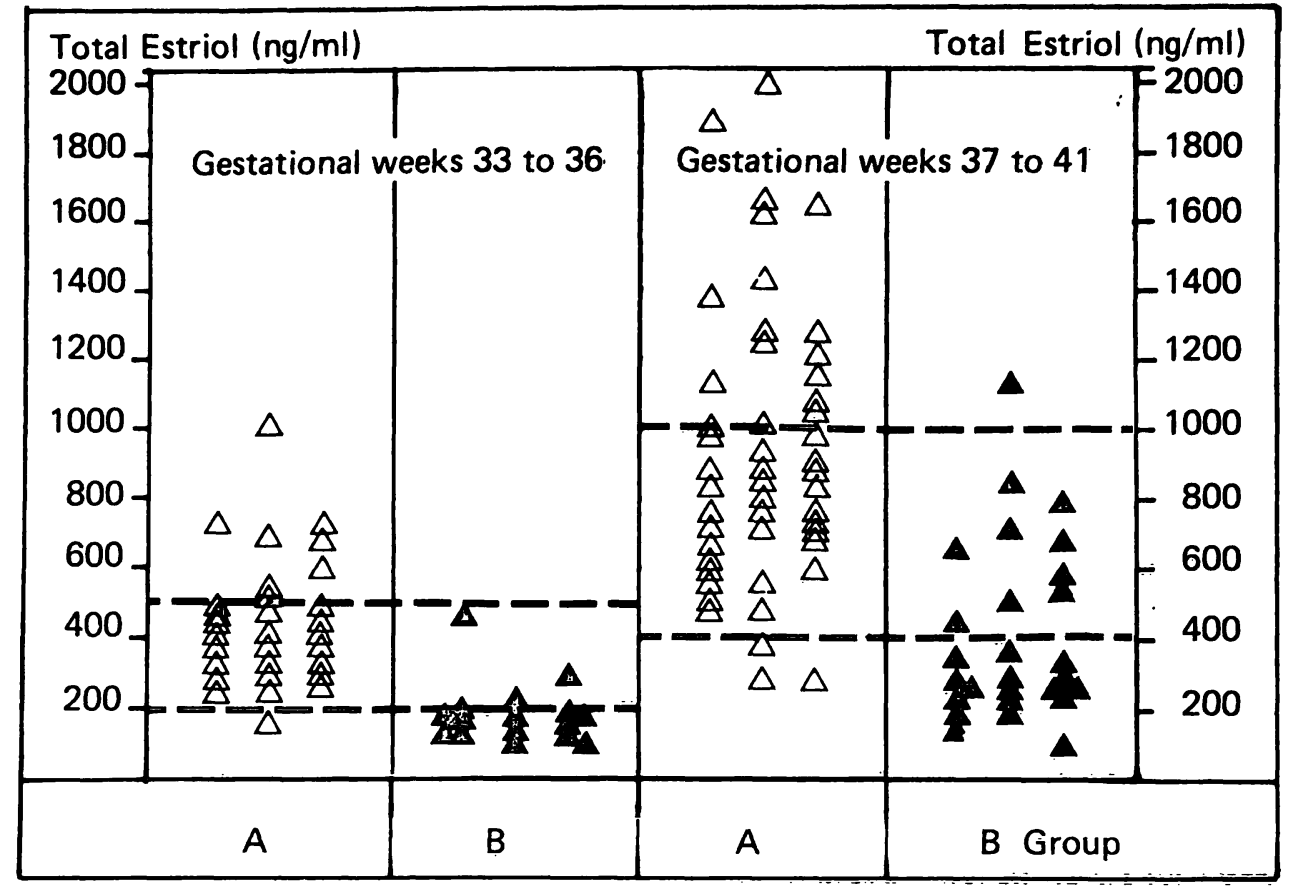

Fig. 4. Distribution within the diagnostic borderlines of total estriol concentrations in amniotic fluid.

Values below the lower borderlines = intrauterine hypotrophy of the infant much likely. Values above the upper borderlines: intrauterine hypotrophy of the infant rather unlikely. $A=$ eutrophic infants, $B=$ hypotrophic infants.

\begin{tabular}{|l|l|l|l|l|l|l|l|}
\hline & $n$ & $\begin{array}{l}\text { Total estriol } \\
(\mathrm{ng} / \mathrm{ml}) \overline{\mathrm{x}} \pm \mathrm{s}\end{array}$ & $\frac{\mathrm{TE} 3 \overline{\mathrm{x}}(\mathrm{B})}{\mathrm{TE} 3 \overline{\mathrm{x}}(\mathrm{A})}$ & $\begin{array}{l}\text { Mean body } \\
\text { weight }(\mathrm{g})\end{array}$ & $\frac{\mathrm{BW} \overline{\mathrm{x}}(\mathrm{B})}{\mathrm{BW} \overline{\mathrm{x}}(\mathrm{A})}$ & $\begin{array}{l}\text { Mean } \\
\text { placental } \\
\text { weight }(g)\end{array}$ & $\frac{\mathrm{PW} \overline{\mathrm{x}}(\mathrm{B})}{\mathrm{PW} \overline{\mathrm{x}}(\mathrm{A})}$ \\
\hline $\begin{array}{l}\text { Eutrophic } \\
\text { neonates (A) }\end{array}$ & 38 & $995.8 \pm 485.0$ & -- & 3274 & -- & 578 & -- \\
\hline $\begin{array}{l}\text { Hypotrophic } \\
\text { neonates (B) }\end{array}$ & 18 & $466.9 \pm 281.5$ & 0.47 & 2384 & 0.73 & 435 & 0.75 \\
\hline
\end{tabular}

Tab. IV. Total estriol concentrations in amniotic fluid at the day of delivery (TE 3), body weights (BW) and placental weights (PW) in eutrophic and hypotrophic, term babies.

In normal pregnancies numerous investigators have studied estriol levels in amniotic fluid. There are, however, relatively few detailed and representative studies of estriol in amniotic fluid as to special disturbances or diseases in pregnancy $[8,10,15$, 21]. Obviously, estriol assays in amniotic fluid might contribute to antenatal identification of the high-risk hypotrophic fetus, as it could be shown in this study.

Further investigations should be made to clarify which relative predictive value for the antenatal diagnosis of fetal hypotrophy is to be ascribed to estriol assays in amniotic fluid as compared to those in maternal plasma. Comparative determinations of absolute estriol amounts in amniotic fluid in pregnancies with eutrophic and hypotrophic infants might also be interesting. Of course, for such a study simultaneous determinations of the actual estriol concentration and of the actual total volume of amniotic fluid would have to be carried out. 


\section{Summary}

In 108 pregnancies (gestational weeks 31 to 41 ) 127 samples of amniotic fluid were assayed for their concentrations of total estriol. Among the pregnancies examined there were 74 pregnancies with eutrophic infants (Group A) and 34 with hypotrophic infants (Group B). The infants were classified in one of the two groups by gestational age and birthweight. Hypotrophic infants were defined as infants whose birthweight lay below the 3 rd percentile in the intrauterine growth curves according to NICKL.

Ante partum the samples of amniotic fluid were obtained by transabdominal amniocentesis, sub partu by transcervical amniocentesis. For total estriol assay in amniotic fluid a chemical method was applied which afforded direct quantification of the chromatographically pure estriol spots by means of reflectance spectrophotomctry after TLC separation of the estrogenic extracts.

Taken as a whole, total estriol concentrations in amniotic fluid were much lower in pregnancies with hypotrophic infants than in those with eutrophic infants : at gestational weeks 37 to 41 Group A $943.8 \pm 464.8 \mathrm{ng}$ per ml, Group B $392.2 \pm 258.9 \mathrm{ng}$ per ml, at gestational weeks 33 to 36 Group A $430.0 \pm 191.7 \mathrm{ng}$ per ml, Group B $185.7 \pm 86.2$ ng per $\mathrm{ml}$. The group differences were statistically significant $\left(x^{2}\right.$-test, $\left.\mathrm{P}<0.001\right)$. As there was a considerable overlapping of the values in both groups, a low normal total estriol concentration in amniotic fluid did not ex- clude fetal hypotrophy with certainity. Determinate marginal estriol concentrations proved to be of diagnostic and prognostic importance. At gestational weeks 33 to 36 and 37 to 41 total estriol levels in amniotic fluid below $200 \mathrm{ng}$ per $\mathrm{ml}$ and below $400 \mathrm{ng}$ per $\mathrm{ml}$ respectively indicated fetal hypotrophy to be much likely. In contrast, values above $500 \mathrm{ng}$ per $\mathrm{ml}$ and above $1000 \mathrm{ng}$ per $\mathrm{ml}$ at gestational weeks 33 to 36 and 37 to 41 respectively were generally not consistent with hypotrophy of the infants.

The comparison of the birthweights and total estriol concentrations in amniotic fluid obtained subpartally from eutrophic and hypotrophic term neonates was interesting. The mean relative weight deficit in the hypotrophic newborn infants ( 27 per cent) was much smaller than their mean relative estriol deficit in amniotic fluid ( 53 per cent). The perinatal high risk in the hypotrophic group examined was revealed in the following clinical data : perinatal mortality 8.8 per cent (vs 1.4 per cent in the eutrophic group), respiratory and metabolic acidosis immediately after delivery 29.5 per cent (vs. 12.1 per cent), and depressions of the infants immediately after delivery 32,4 per cent (vs. 12.1 per cent).

In the hypotrophic group, the rate of maternal complications in pregnancy amounted to 55.9 per cent, in the eutropic group, however, only to 5.4 per cent.

Keywords: Amniotic fluid, fetus, fetal hypotrophy, newborn infant, total estriol assays.

\section{Zusammenfassung}

Die Rolle von Gesamtöstriol-Bestimmungen im Fruchtwasser zur Diagnose der fetalen Hypotrophie

127 Fruchtwasserproben von 108 Schwangerschaften (Gestationswochen 31-41) wurden auf ihre Konzentrationen an Gesamtöstriol untersucht. Von den untersuchten Schwangerschaften waren 74 Schwangerschaften mit eutrophen Kindern (Gruppe A) und 34 Schwangerschaften mit hypotrophen Kindern (Gruppe B). Die Klassifizierung in eutrophe oder hypotrophe Gruppe richtete sich nach Gestationsalter und Geburtsgewicht. Als hypotrophe Kinder wurden Neugeborene definiert, deren Geburtsgewicht unter der 3 . Perzentile der intrauterinen Wachstumskurve nach NICKL lag.

Die Fruchtwasserproben wurden ante partum durch transabdominale Amniozentese gewonnen, sub partu durch Blasensprengung. Zur Bestimmung des Gesamtöstriols im Fruchtwasser wurde eine chemische Methode angewendet, die nach dünnschichtchromatographischer Trennung eine direkte Quantifizierung der chromatographisch reinen Östrolflecke mittels Remissions-Spektrophotometrie gestattet.

Im ganzen gesehen, lagen die Gesamtöstriolwerte im Fruchtwasser bei Schwangerschaften mit hypotrophen Kindern viel niedriger als bei Schwangerschaften mit eutrophen Kindern: in den Schwangerschaftswochen 37-41 Gruppe A $943,8 \pm 464,8 \mathrm{ng} / \mathrm{ml}$, Gruppe B 392,2 \pm $258,9 \mathrm{ng} / \mathrm{ml}$, in den Schwangerschaftswochen 33-36 Gruppe A $430,0 \pm 191,7 \mathrm{ng} / \mathrm{ml}$, Gruppe B $185,7 \pm 86,2$ $\mathrm{ng} / \mathrm{ml}$. Die Gruppendifferenzen waren statistisch signifikant
$\left(X^{2}\right.$-Test; $\left.p<0,001\right)$. Da eine beträchtliche Überlappung der Werte beider Gruppen bestand, schloß ein normaler Gesamtöstriolwert im Fruchtwasser eine Hypotrophie des Feten nicht mit Sicherheit aus.

Bestimmte Östriolwerte erwiesen sich als von erheblichem Diagnose- und Prognosewert. In den Schwangerschaftswochen 33-36 bzw. 37-41 deuteten Gesamtöstriol-Konzentrationen im Fruchtwasser unter $200 \mathrm{ng} / \mathrm{ml}$ bzw. $400 \mathrm{ng} / \mathrm{ml}$ mit großer Wahrscheinlichkeit auf eine fetale Hypotrophie hin. Demgegenüber schlossen Werte über $500 \mathrm{ng} / \mathrm{ml} \mathrm{bzw} .1000 \mathrm{ng} / \mathrm{ml}$ in den Schwangerschaftswochen 33-36 bzw. 37-41 eine fetale Hypotrophie weitgehend aus.

Interessant war der Vergleich der subpartualen Gesamtöstriol-Konzentrationen im Fruchtwasser und der Geburtsgewichte von eutrophen und hypotrophen, am Termin geborenen Kindern. Das mittlere relative Gewichtsdefizit $(27 \%)$ der hypotrophen Neugeborenen war viel geringer als ihr mittleres relatives Östrioldefizit im Fruchtwasser $(53 \%)$.

Das hohe perinatale Risiko der untersuchten hypotrophen Kinder kam in den folgenden klinischen Daten zum Ausdruck: perinatale Mortalität $8,8 \%$ (vs. eutrophe Kinder $1,4 \%$ ), Depression unmittelbar post partum $32,4 \%$ (vs. $5,4 \%)$, respiratorische und metabolische Azidosen unmittelbar post partum $29,5 \%$ (vs. $12,1 \%$ ). In der hypotrophen Gruppe betrug die Rate der mütterlichen Schwangerschaftskomplikationen $55,9 \%$, in der eutrophen Gruppe dagegen nur $5,4 \%$.

Schlüsselwörter: Fet, Fruchtwasser, Gesam töstriol-Bestimmungen, fetale Hypotrophie, Neugeborenes. 


\section{Résumé}

Le rôle des dosages d'oestriol total du liquide amniotique pour le diagnostic de l'hypotrophie foetale Le présent article porte sur l'examen des concentrations d'oestriol total de 127 échantillons de liquide amniotique de 108 grossesses (semaine de gestation entre 31 et 41 ). Sur ces 108 grossesses, 74 mirent à terme des enfants eutrophes (Groupe A) et 34 des enfants hypotrophes (Groupe B). Le classement en groupe eutrophe ou hypotrophe s'opéra d'après l'àge de gestation et le poids à la naissance. On a défini comme enfants hypotrophes les nouveaux-nés dont le poids de naissance était inférieur au 3 pourcentile de la courbe de croissance intrautérine d'après NICKL.

Les échantillons de liquide amniotique ont été obtenus ante partum par amniocentèse transabdominale, sub partu par amniocentèse transcervicale. Pour le dosage d'oestriol total du liquide amniotique, on a utilisé une méthode chimique qui, après séparation de couches minces chromatographique, permet une quantification directe de la tache d'oestriol chromatographiquement pure par spectrophotométrie de rémission.

Considérées dans leur ensemble, les valeurs d'oestriol total du liquide amniotique ont été nettement plus basses dans les grossesses avec enfants hypotrophes que dans celles avec enfants eutrophes: dans les semaines de grossesse 37-41 Groupe A 943,8 $\pm 464,8 \mathrm{ng} / \mathrm{ml}$, Groupe. B 392,2 \pm $258,9 \mathrm{ng} / \mathrm{ml}$, dans les semaines de grossesse 33-36 Groupe A $430,0 \pm 191,7 \mathrm{ng} / \mathrm{ml}$, Groupe B $185,7 \pm 86,2 \mathrm{ng} / \mathrm{ml}$. Les différences entre les groupes ont été statistiquement significatives $\left(\mathrm{X}^{2}\right.$-Test; $\left.\mathrm{p}<0,001\right)$. Un recoupement très important ayant été observé, ęntre les valeurs des deux groupes, une valeur normale d'oestriol total du liquide amniotique n'exclut pas absolument une hypotrophie du foetus.

Certaines valeurs d'oestriol se sont avérées comme étant d'une grande signification pour le diagnostic et le pronostic. Dans les 33-36 ou 37-41 èmes semaines de grossesse, les concentrations d'oestriol total du liquide amniotique inférieures à respectivement $200 \mathrm{ng} / \mathrm{ml}$ ou $400 \mathrm{ng} / \mathrm{ml}$ ont indiqué avec un degré de probabilité élevé une hypotrophie foetale. Au contraire, les valeurs supérieures à respectivement $500 \mathrm{ng} / \mathrm{ml}$ ou $1000 \mathrm{ng} / \mathrm{ml}$ dans les semaines de grossesse entre 33 et 36 ou 37 et 41 ont largement confirmé l'exclusion d'une hypotrophie foetale.

Une observation intéressante a résulté de la comparaison des concentrations subpartuales d'oestriol total du liquide amniotique et des poids de naissance des enfants eutrophes et hypotrophes nés à terme. Le déficit de poids relatif moyen $(27 \%)$ des nouveaux-nés hypotrophes s'est montré de beaucoup inférieur à son déficit d'oestriol relatif moyen dans le liquide amniotique (53\%).

Le risque périnatal élevé des enfants hypotrophes examinés se manifesta dans les données cliniques suivantes: mortalité périnatale $8,8 \%$ ( $v s^{\prime}$ enfants eutrophes $1,4 \%$ ), dépression directement post partum $32,4 \%$ (vs. 5,4\%) acidoses respiratoires et métaboliques directement post partum $29,5 \%$ (vs. $12,1 \%$ ). Dans le groupe hypotrophe, le taux des complications de grossesse maternelles s'éleva à $55,9 \%$ contre seulement $5,4 \%$ dans le groupe eutrophe.

Mots-clés: Dosages d'oestriol total, foetus, hypotrophie foetale, liquide amniotique, nouveau-né.

\section{Acknowledgement}

This study was supported by a grant from the Deutsche Forschungsgemeinschaft, Bonn-Bad Godesberg, Federal Republic of Germany.

\section{Bibliography}

[1] BACIGALUPO, G., G. KYNAST, J. W. DUDENHAUSEN, E. SALING: Neuartige Methode zur spezifischen Östriolbestimmung im Plasma und Urin von Schwangeren sowie im Fruchtwasser. In: DUDENHAUSEN, J. W., E. SALING, E. SCHMIDT (eds.), Perinatale Medizin, Band VI, pp. 141-143, Thieme, Stuttgart, 1975

[2] BIGgS, J. S., R. O. DUNCAN: Production rate and sources of amniotic fluid at term. J. Obstet. Gynaec. Brit. Cwlth. 77 (1970) 326

[3] DICZFALUSY, E., S. MANCUSO: Oestrogen metabolism in pregnancy. In: KLOPPER, A., E. DICZFALUSY (eds.): Fetus and Planceta. Oxford, Blackwell Scientific Publ. 1969 pp. 191-248

[4] DOBBING, J.: The effect of undernutrition on myelination in the central nervous system. Biol. Neonat. 9 (1965) 132

[5] DRILLIEN, C. M.: The small-for-date infant: Etiology and prognosis. Pediatr. Clin. North Amer. 17 (1970) 9
[6] FARR, V., R. G. MITCHELL, G. A. NELLIGAN, J. M. PARKIN: The definition of some external characteristics used in the assessment of gestational age of the newborn infant. Develop. Med. Child. Neurol. 8 (1966) 507

[7] FENCL, M. DE, C. ALONSO, M. ALBA: Estriol values in amniotic fluid in the course of normal pregnancy. Amer. J. Obstet. Gynecol. 113 (1972) 367

[8] HÄFFELE, R., G. EICHELBERG, A. KÖNIG: Östrogene und Cortisol im Fruchtwasser bei normal und pathologisch verlaufenden Schwạngerschaften. Z. Gebh. Perinat. 179 (1975) 437

[9] J $\emptyset$ RGENSEN, P. I., V. A. FRANDSEN, B. SVENSTRUP: Amniotic fluid oestriol concentration during the last trimester of pregnancy. Part I. Acta Obstet. Gynaecol. Scand. 53 (1974) 23

[10] J $\emptyset$ RGENSEN, P. I., V. A. FRANDSEN, B. SVENSTRUP: Amniotic fluid oestriol concentration 
during the last trimester of pregnancy. Part II. Acta Obstet. Gynaecol. Scand. 53 (1974) 29

[11] KEUTH, U.: Pränatale Dystrophie. In: OPITZ, H., F. SCHMID, (eds.): Handbuch der Kinderheilkunde I/2, pp. 515-529. Springer, Berlin-HeidelbergNew York, 1974

[12] KLINGMÚLLER-AHTING, U., E. SALING, J. GIFFEI: Frühgeburt und intrauterine Mangelentwicklung. Gynaekol. 8 (1975) 186

[13] LOW, J. A., R. W. BOSTON, S. R. PANCHAM: Fetal asphyxia during the intrapartum period in intrauterine growth-retarded infants. Amer. J. Obstet. Gynecol. 113 (1972) 351

[14] MAIER, U. E. K.: Prä- und postnataler ProteinKalorien-Mangel und Gehirnentwicklung. Fortschr. Med. 93 (1975) 726, 771, 821 (3 parts)

[15] MICHIE, E. A., J. G. ROBERTSON: Amniotic and urinary oestriol assays in pregnancies complicated by Rh-immunization. J. Obstet. Gynaecol. Brit. Cwlth. 78 (1971) 34

[16] NICKL, R.: Standardkurven der intrauterinen Entwicklung von Gewicht, Länge und Kopfumfang. Inaugural-Dissertation, München, 1972
[17] PETRUSSA, J.: A scoring system for the assessment of gestational age of newborn infants. In: HUNTINGFORD, P. J., R. W. BEARD, F. E. HYTTEN, J. W. SCOPES (eds.): Perinatal Medicine. Proc. 2nd Europ. Congr. Perinatal Medicine, 1970. Basel, Karger, 1971

[18] SALING, E.: Zustandsdiagnose beim Neugeborenen unmittelbar nach der Geburt. Gynaecologia 160 (1965) 133

[19] SCHINDLER, A. E.: Steroide im Fruchtwasser. Fortschr. Geburtsh. Gynäkol. 46 (1972) 1

[20] SCHINDlER, A. E., V. RATANASOPA: Profile of steroids in amniotic fluid of normal and complicated pregnancies. Acta endocrinol. (Kbh) 59 (1968) 239

[21] TIKKANEN, M. J.: Oestriol conjugates in amniotic fluid. Qualitative and quantitative aspects including preliminary studies in Rh-immunization. Acta endocrinol. (Kbh) 73 (1973) 555

[22] WINICK, M.: Malnutrition and brain development. J. Pediatr. 74 (1969) 667

[23] WINICK, M., P. ROSSO: The effect of severe early malnutrition on cellular growth of human brain. Pediat. Res. 3 (1969) 181

Received March 10, 1976. Accepted December 13, 1976.

Prof. Dr. G. Bacigalupo, Unit of Perinatal Medicine, The Free University of Berlin, Mariendorfer Weg 28-38 1000 Berlin 44, Germany 